Abbreviated Key Title: Sch J Med Case Rep

ISSN 2347-9507 (Print) | ISSN 2347-6559 (Online)

Journal homepage: https://saspublishers.com/sjmcr/

\title{
Adenomyoma of the Duodenum Producing Common Bile Duct Obstruction
}

Ayman Chakiri", Dahmane H, Elazaoui F, Hama Y, Elmalki HO, Chefchaouni M, Iffrine L, Belkouchi A

Surgical Department A, Faculty of Medicine and Pharmacy, Mohammed 5 University, Ibn Sina Hospital, Rabat, Morocco

DOI: $\underline{10.36347 / \text { sjmcr.2020.v08i08.003 }}$

| Received: 30.07.2020 | Accepted: 07.08.2020 | Published: 08.08.2020

*Corresponding author: Ayman Chakiri

Abstract

Case Report

The duodenal adenomyoma is a benign lesion clinically, radiologically and during surgery simulating tumor pathology, in particular vaterian ampulloma. These similarities lead to the performance of unnecessary cephalic duodenopancreatectomy. We report a case of duodenal adenomyoma leading to cephalic duodenopancreatectomy.

Keywords: Cephalic duodenopancreatectomy, adenomyoma, icterus.

Copyright @ 2020: This is an open-access article distributed under the terms of the Creative Commons Attribution license which permits unrestricted use, distribution, and reproduction in any medium for non-commercial use (NonCommercial, or CC-BY-NC) provided the original author and source are credited.

\section{INTRODUCTION}

Adenomyoma affecting the gastrointestinal tract is generally recognized as a form of pancreatic heterotopia. The location of the adenomyoma is often in the stomach and duodenum. Clinical signs depend on the location and size of the lump, many being asymptomatic and incidental findings. In this report, we will describe the case of a patient who presents with a duodenal adenomyoma discovered after cholestatic jaundice, and who presents on radiological examinations as a vaterian ampulloma and treated by a cephalic duodenopancreatectomy.

\section{CASE REPORT}

We report the case of a 49-year-old man, with no notable pathological history, who has presented fluctuating icterus for 2 months with pain in the right hypochondrium with episodes of unstated fever. The general examination finds a patient a patient in good general condition, pale, with subicterus. Abdominal examination finds a supple abdomen with no palpable mass.

Laboratory tests show anemia at $9.5 \mathrm{G} / \mathrm{dl}$, TP at $64 \%$, total bilirubin at $18 \mathrm{mg} / 1$ (indirect bilirubin at $11 \mathrm{mg} / \mathrm{L}$ ), negative tumor marker: CA $19.9<2.00 \mathrm{IU} /$ $\mathrm{ml}$ and $\mathrm{ACE}=1.63 \mathrm{ng} / \mathrm{mL}$. The remainder of the biological balance is unremarkable.

Abdominal CT scan was performed showing intrahepatic biliary dilation and the main bile duct upstream of a lower common bile duct obstruction (Fig $1)$.

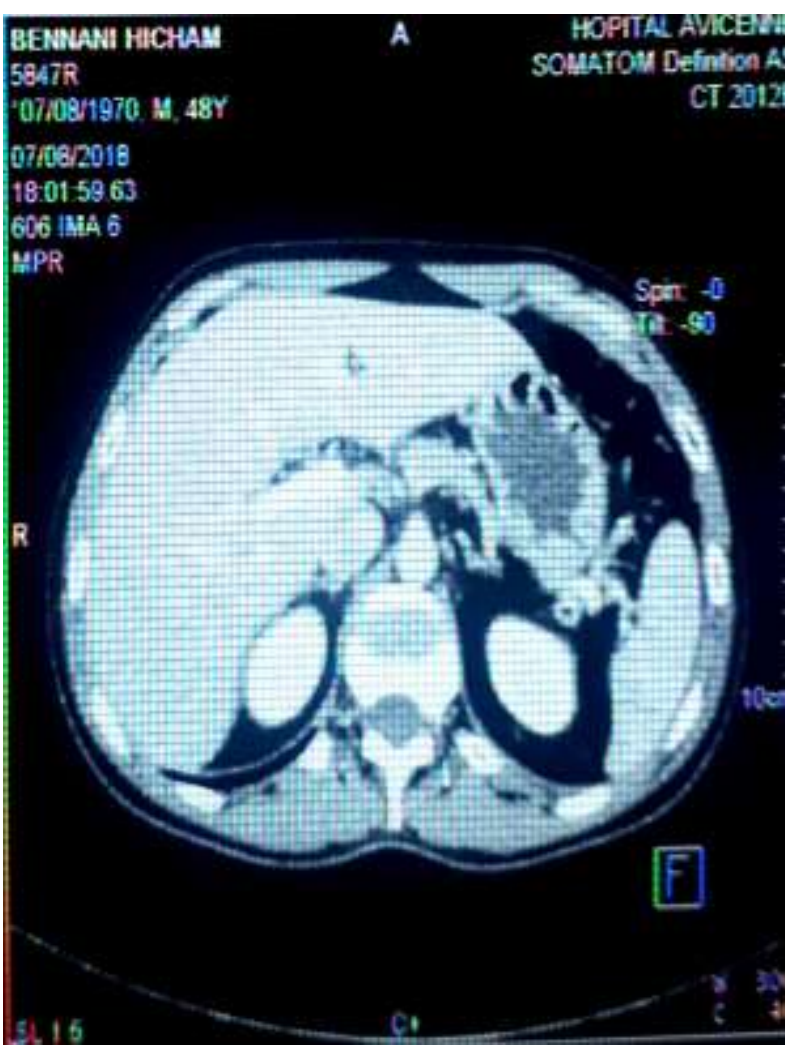

Fig-1: Abdominal CT scan showing dilation of the main bile duct

It was completed by an MRI which showed a dilation of the main bile duct to $13 \mathrm{~mm}$, upstream of a small mass of $10 \mathrm{~mm}$ well limited sitting at the level of the 2nd duodenum opposite the small duodenal papilla, it is definitely hyperintense in $\mathrm{T} 2$, and is enhanced very discreetly after injection of contrast product. Compatible with vaterian ampulloma. The thoraco- 
pelvic extension assessment does not show any secondary location (Fig 2-3).

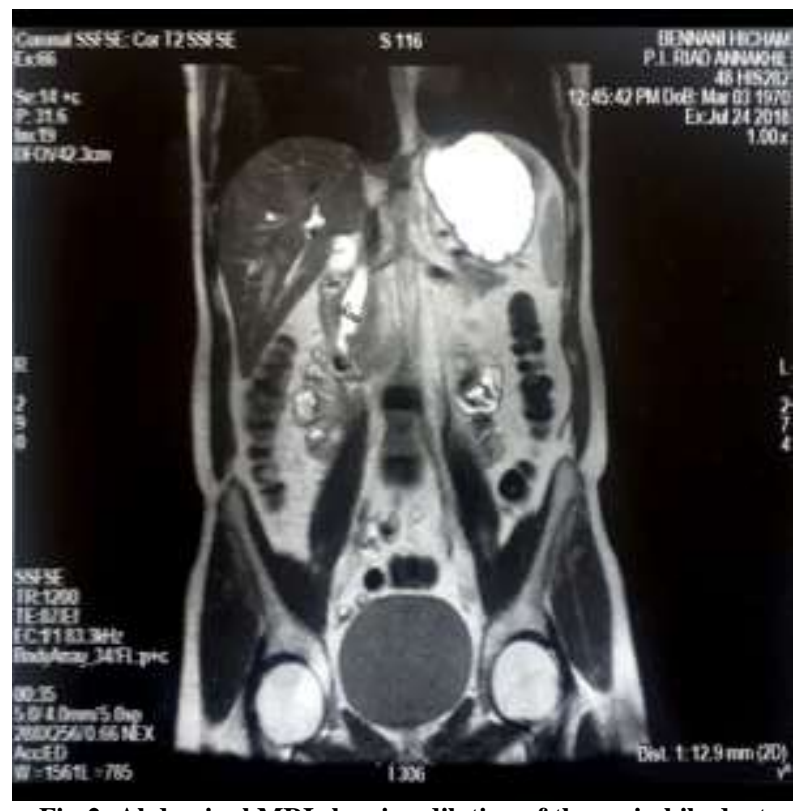

Fig-2: Abdominal MRI showing dilation of the main bile duct upstream of a duodenal mass at the level of the vater bulb

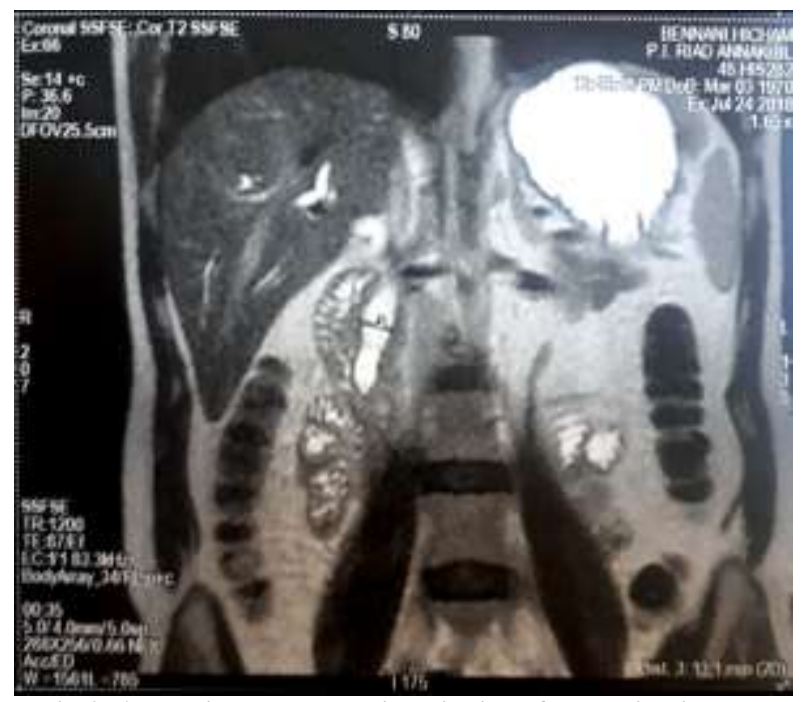

Fig-3: Abdominal MRI showing dilation of the main bile duct upstream of a duodenal mass at the level of the vater bulb

After transfusion and conditioning, he was managed surgically and had a cephalic duodenopancreatectomy. The post-operative consequences were simple.

The anatomopathological study of the operative part was in favor of a duodenal adenomyoma, without histological signs of malignancy.

\section{DISCUSSION}

Pancreatic heterotopia represents a developing condition in which there is displaced pancreatic tissue in various parts of the gastrointestinal tract. It occurs as a mass consisting of smooth muscles and epithelial structures in varying amounts and histologically appearing, leading to confusing terminology. When typical pancreatic acinar tissue is present, the mass is called an ectopic or aberrant pancreas. This is the most common form. When a preponderance of smooth muscle is present along with the ductal structures, the term adenomyoma is used. Clarke proposed the term myoepithelial hamartoma to include all of these developmental conditions [1]. Cimmino has discussed the terminology in detail and prefers the umbrella term adenomyosis [2].

Heterotopic pancreatic tissue at the gastrointestinal level tract is not a rare abnormality. The exact the incidence of adenomyomas is difficult to determine.

Most are found in the upper gastrointestinal tract extensive, most within $5-6 \mathrm{~cm}$ of the pylorus. Ninety percentages of tumors reported by the Mayo Clinic were in the stomach, duodenum and jejunum [3]. Other sites in the gastrointestinal tract and structures in the thorax are less frequently involved. The bile tract is a rare localization and an obstruction of the common duct has been reported in eight cases, including three lesions located in the common bile duct and five in the ampulla of Vater $[4,5]$. The importance of heterotopic pancreatic tissue in producing symptoms depends on the location and size of the tumor mass $[3,4,6]$.

For example, a lesion near the pylorus produces symptoms of obstruction of the gastric outlet. Ulcerations and bleeding can occur. Pathological processes that take place in normal pancreatic tissue, such as pancreatitis and malignancy, can also occur in heterotopic tissue. In our patient, the location of the lesion in the duodenum near the ampulla was responsible for the compression and obstruction of the common bile duct, resulting in cholestasis. Preoperatively, the lesion was considered and treated as vateria ampulloma.

\section{Conflict of interest}

The authors have no conflict of interest to declare.

\section{REFERENCES}

1. Clarke BE. Myoepithelial hamartoma of the gastrointestinal tract: a report of eight cases with comment concerning genesis and nomenclature. Arch. Pathol. 1940; 30:143-52.

2. Cimmino CV. Gastric adenomyosis vs. aberrant pancreas. Radiology. 1955 Jul;65(1):73-7.

3. Dolan RV, ReMine WH, Dockerty MB. The fate of heterotopic pancreatic tissue: a study of 212 cases. Archives of Surgery. 1974 Dec 1;109(6):762-5.

4. PEARSON S. Aberrant pancreas: review of the literature and report of three cases, one of which produced common and pancreatic duct obstruction. 
Ayman Chakiri et al., Sch J Med Case Rep, August, 2020; 8(8): 760-762

AMA Archives of Surgery. 1951 Aug 1;63(2):16884.

5. Mitchell N, Augrist A. Myoepithelial hamartoma of the gastrointestinal tract. Ann Intern Med.1943; 19:952
6. Barbosa Dockerty MB, Waugh JM. Pancreatic heterotopia. Surg Gynecol Obstet.1946; 82:527. 